\title{
RESEARCHING THE COMPETITIVENESS OF THE FISHING INDUSTRY IN THE REGION OF THE BALTIC COUNTRIES
}

\author{
SEBASTIAN KUBALA \\ CHRYSTIAN FIRLEJ
}

\begin{abstract}
The main objective of this article is to examine the level of competitiveness of the fishing industry in the countries of the Baltic region. The current socio-economic conditions have caused that there is a diverse degree of demand for fish products, different level of development of foreign trade and diverse possibilities of obtaining fish organisms through the development of aquaculture in individual Baltic states. The calculations performed in the study used such methods as DEA index and Trade Coverage index. Calculating the indicators made it possible to demonstrate that there is a significant variation in the degree of competitiveness of the fishing industry in the Baltic countries, while there is also a diversity in terms of the development of aquaculture, importance of foreign trade in fish products and relevance of the entire fish market.
\end{abstract}

Keywords: fishing industry, aquaculture, fish catches, fishing fleet.

JEL codes: O13, O52, Q22, Q17.

\section{Introduction}

In the food chain, the process of getting fish, which follows from the need to meet the existential needs of the society, is one of the main sections of the food economy not only in Europe, but also all over the world. In recent years, the fishing industry in the Baltic Rim countries has gradually evolved. The growing demand for and consumption of fish, along with the gradual development resulting from

Mgr Sebastian Kubala, Uniwersytet Ekonomiczny w Krakowie, Katedra Strategii Zarządzania i Rozwoju Organizacji, ul. Rakowicka 27, 31-510 Kraków (kubalas@uek.krakow.pl).

Mgr Chrystian Firlej, Uniwersytet Rolniczy w Krakowie, al. Mickiewicza 21, 31-120 Kraków (chrystianf@poczta. onet.pl). 
progressive globalisation, have become the main determinants of the current state of the fish market. The openness of the economies is an important factor for this industry due to the fact that many of its products have a short shelf-life. At present, the quality of products is more important for the buyer than their price. The introduction of rigorous standards for fish products, a necessity to hold required certificates, the requirements on determining the origin of products become the conditions to be met by companies operating in the fish industry ${ }^{1}$. All this makes the fish industry in the countries of the Baltic region significantly diversified in terms of their market position. The ability of the individual countries to compete among themselves has long been recognised, which is expressed by conducting studies in this area, inter alia, by the World Economic Forum which since 1979 has been using the Global Competitiveness Index, and since 2012 - also the Europe 2020 Competitiveness Index.

According to Kukuła and Strojny, the subject of the studies on competitiveness is most often an enterprise or a national economy, and less often it is an industry. The precise definition of the term of competitiveness is a very complex process (Kukuła and Strojny, 2010). As pointed out by Pierścionek (2003), there are many definitions of competitiveness in literature. Most of them are similar, and differ only in terms of the way the problem is formulated, which makes it possible to recognise the difference among them as irrelevant. On the other hand, Gorynia (2000) notes that the definitions of competitiveness are generally prepared from the perspective of the studies conducted. It is important that this concept can be seen from the point of view of various operators, as well as markets of various coverage (Filip and Sowa, 2008; Urbaniak, 2007). Most generally, the concept of competitiveness can be defined as an ability to achieve one's objectives in competing with other operators on the market. For the purposes of the paper, the competitiveness is divided into the factor competitiveness and the result competitiveness (Grzebyk and Kryński, 2011). The former is to highlight the factors influencing the ability of operators to compete effectively, in particular, the ability to use the resources or the ability to use the configuration of the environment. The result competitiveness is, in turn, to determine the results of competing, mainly by indicating the competitive position of the analysed operator, defined on a basis of foreign trade data.

So far, attempts to determine the level of competitiveness of the fish industry have been made by Batzios, Kaimakoudi and Polymeros (2014) who studied the competitiveness in the Balkans and Central and Eastern Europe, and by Hameri and Palsson (2003) who focused on the fish industry in Iceland. However, in those studies they referred only to the assessment of competitiveness based on the results achieved in international trade.

The main objective of this article is to attempt to study the competitive position of the fish industry in the countries of the Baltic region. As a result of the current socio-economic conditions in the Baltic Rim countries, there is a diversified level

\footnotetext{
${ }^{1}$ Production classification of the fish industry consistent with ISIC: section D, class 1512 .
} 
of demand for fish products, degree of foreign trade development or different opportunities to obtain fish organisms through the development of aquaculture. The fish industry is an important part of the food market, which affects its functioning as a whole and is an important part of the national economic space, particularly in the coastal countries. A characteristic feature of the fish industry is the low level of self-sufficiency, which is associated with a significant dependence of the market on import. Because of this operators in the market have broad knowledge, both about the processes taking place on the global market and the geopolitical, environmental or economic terms, which translates into the relevance of actions undertaken in a short and long term, and determines the efficiency in operation in the everchanging conditions (Hryszko, Kuzebski and Lirski, 2014).

The studies deliberately referred to a wide range of indices allowing to measure the level of efficiency and competitiveness of the industry in the analysed countries: Denmark, Estonia, Finland, Germany, Norway, Poland, Sweden, Lithuania and Latvia. Therefore, a reference was made to the volume of fish catches in relation to the held fleet, the volume of fish catches per capita, the level of development of aquaculture, the productivity of the industry as measured by the DEA index and the degree of foreign trade competitiveness, as measured by the TC indicator. Based on these indices, the point, holistic assessment of the degree of competitiveness was made.

The article decided to solve the problem of whether there is a significant degree of diversification in the fishing industry's competitiveness in the Baltic Rim countries, with the diversification of the development of aquaculture, the importance of foreign trade in fish products and importance of the whole fish market in the given country. The studies have been conducted using the method of analysing the literature of the subject, in particular, annual reports relating to the fish industry of the individual countries and statistical data analysis.

\section{Description of the method}

The issue of the studies on the competitiveness of the agri-food sector is very complicated. One possibility of assessing the competitiveness of this sector, as well as its ability to compete, consists in relying on many different indicators. As pointed out by Latrufee (2010), it is reasonable to divide them into two groups: indices based on the foreign trade results and indices based on strategic management, including productivity and efficiency indicators. On this basis, the authors propose to study the competitiveness of the fish market in the Baltic Rim countries by means of the point assessment of the individual countries, considering five indices:

- volume of fish catches/fleet size (W1),

- volume of fish catches/population (W2),

- aquaculture production/volume of fish catches (W3),

- number of people employed in the fish market/volume of fish catches (W4),

- TC index (W5).

These indices were constructed by referring to the three most important possibilities of fish distribution: import, aquaculture and catches. Their design allows for 
the observation of the factors affecting various aspects that influence the degree of competitiveness of the individual countries in the fish industry, i.e. fishing capacity, level of self-sufficiency, development of aquaculture, labour efficiency and export specialisation. In the case of the index illustrating the number of people employed in the fish market in relation to the volume of fish catches, the DEA method was used. Although this method has certain limitations, e.g. the inability to estimate statistical errors of the results obtained or the redundancy of the number of objects rated as best, after Ludwiczak (2014) it was concluded that its greatest advantage is the generality of the approach to the efficiency measurement.

The individual indices were assigned the weight of $0.1-0.3$, by adopting the following assessment scale: 0.1 - the index is highly important for the competitiveness in the analysed industry; 0.2 - the index is important; 0.3 - the index is very important. It is assumed that trade and fishing capacity are the two most important indicators which are the basis for attesting to the competitive position of the state. The index based on the volume of aquaculture production as a source of obtaining fish, which will be increasingly important in the future, received the weight of 0.2. The weight of 0.1 was assigned to the indices W2 and W4. It was considered that the level of self-sufficiency (W2) is an important source of information and, in the event of unforeseen economic fluctuations, the efficiency measured by the DEA method (W4) was rated worst, due to its limitations.

Then, each index for individual countries was assessed using the scale of 1-5 (with a frequency at every 0.5 points), where the lowest value was received by the state with the least desirable result of the index affecting the competitiveness and the highest - the state with the most desirable result. The individual values of the indices are calculated based on the average values of the analysed variables for 2007-2016.

\section{Importance of the fish market in the modern economy}

Analysis carried out is to illustrate the general trends on the fish market in the countries concerned, thus necessitating a division of the fish market into two subsectors where the division criterion is the method of obtaining aquatic organisms (Fig. 1).

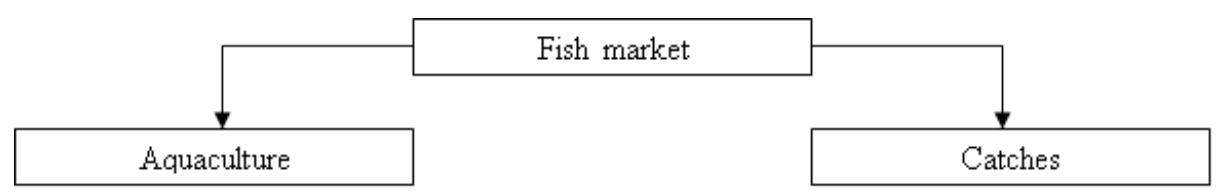

Fig. 1. Division of the fish market by method of obtaining aquatic organisms.

Source: own study based on Hryszko et al. (2014). 
Today, development of aquaculture plays one of the most important roles in the sustainable development of the fish industry. Even in the 1950s, farming of aquatic organisms was virtually unknown and now aquaculture is the major form of farming which satisfies the growing demand for fish. This trend is determined primarily by the reduction in the occurence of aquatic organisms in the natural environment, resulting in a deteriorating state of marine resources. Aquaculture thus becomes an opportunity for the development of local economies and the development of itself can increase the market supply, which should significantly affect price reductions and the acquisition of new customers (Firlej and Kubala, 2017). Focusing on the high quality of the product, which results from using restrictive environmental and consumer regulations, is becoming a priority for farming of aquatic organisms.

The highest share in the aquaculture production in the Baltic Rim countries is that of Norway (91.4\% of the share in the total production value of the Baltic Rim countries in 2015). Norwegian aquaculture has evolved rapidly, taking into account the biological and engineering aspects, as well as the development of new types of farming (Bergheim, 2012). The countries similar in terms of the share of the aquaculture production are Denmark, Poland and Germany (respectively, 2.4\%, 2.2\% and $1.7 \%$ of the overall share). Germany, however, is the country where the highest decrease in the aquaculture production was recorded in 2007-2015 (by more than $40 \%$ ) and in addition to Poland it is the only country where there is a downward trend (in Poland, the decrease was less than 4\%). German aquaculture is unable to meet the demand for fish and seafood and the main source of obtaining fish is import. The fastest growth is observed in the Scandinavian countries such as Sweden and Norway (the rate of changes was, respectively, 228.8\% and 166.3\%). In terms of the share, aquaculture is the most marginal in the post-Soviet countries, i.e. Estonia, Latvia and Lithuania (respectively, $0.05 \%, 0.06 \%$ and $0.27 \%$ of the overall share). These countries are characterised by the gradual development of fish farming, particularly for local purposes (European Maritime and Fisheries Fund Lithuania, 2014; Ruciński, 2017) (Fig. 2).

Since the 1960s, sea catches showed an upward trend, due to the growing number of catches in the Asian continent. Currently, the volume of catches in the European countries has fallen significantly. The main problems faced by the European countries are catch limits in deep-sea fishing and the reduction in the fishing fleet in the European Union countries. 

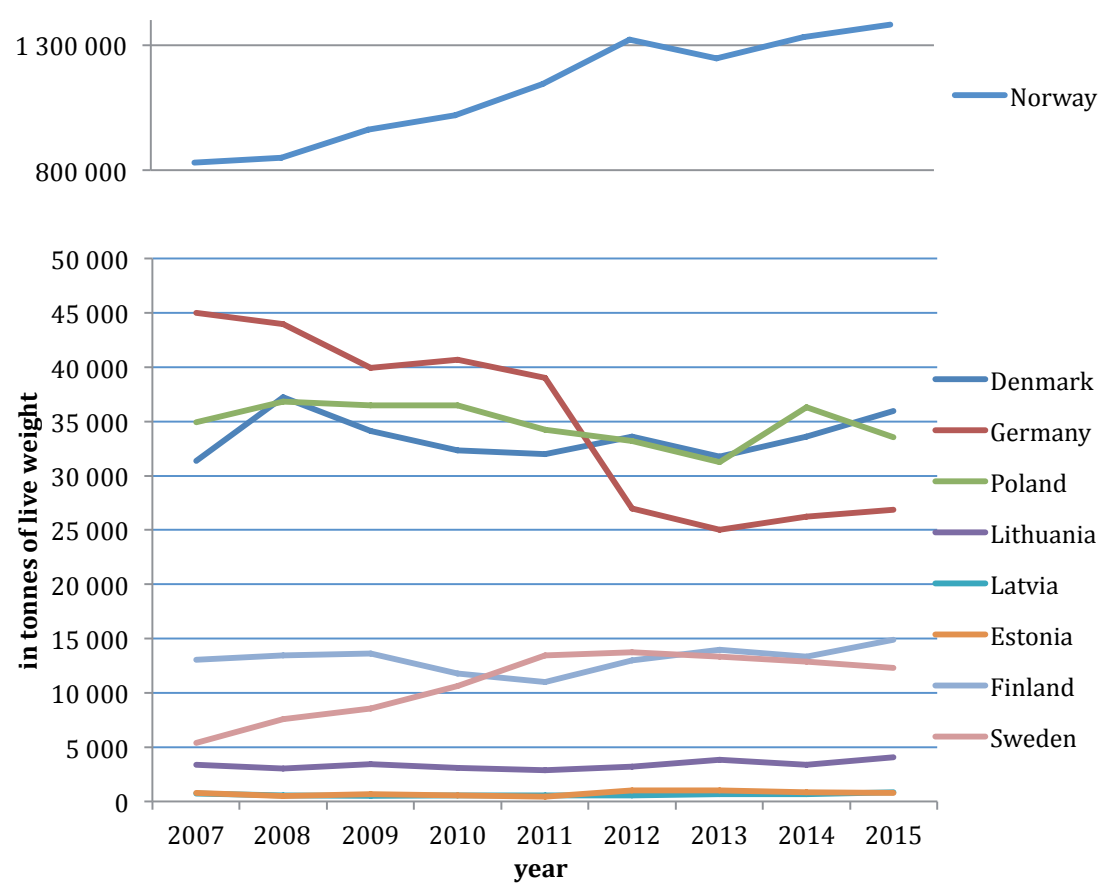

Fig. 2. Aquaculture production exclusive of fish hatcheries and nurseries in the selected European countries 2007-2015 (tonnes of live weight).

Source: own study based on the Eurostat database.

In 2016, the largest share in sea catches among the Baltic Rim countries was that of Norway (51.5\% of the overall share in sea catches in the Baltic Rim countries) followed by Denmark (18.4\% of the share). The remaining Scandinavian countries and the Polish-German region were characterised by a similar catch level ranging from $4.5 \%$ to $6.6 \%$ of the share. The smallest share was that, as in the case of aquaculture, of the post-Soviet countries. It is worth noting that Estonia is the country where the quantity of fish caught in the Baltic Sea is the highest. In 2016, they represented $80 \%$ of the total catch (Eesti Statistika Kvartalikiri, 2017). In 2007-2016, the increase in the volume of catches was recorded only in four countries: Poland, Finland, Germany and Denmark (increase by, respectively: 57.1\%, 26.9\%, 6.0\% and 2.6\%). In Lithuania and Latvia, this method of acquiring raw material was eliminated to the highest extent (Table 1). 
Sea catches in the selected European countries in 2007-2016

Table 1

(thousand tonnes of live weight)

\begin{tabular}{lcccccccccc}
\hline \multicolumn{1}{c}{ Country } & 2007 & 2008 & 2009 & 2010 & 2011 & 2012 & 2013 & 2014 & 2015 & 2016 \\
\hline Denmark & 653.0 & 690.6 & 777.7 & 828 & 716.2 & 502.6 & 668.3 & 745.0 & 868.9 & 670.2 \\
Germany & 226.9 & 207.4 & 195.0 & 214.9 & 217.7 & 205.4 & 219.0 & 216.2 & 251.3 & 240.6 \\
Poland & 125.3 & 115.5 & 175.0 & 130.4 & 175.6 & 179.7 & 195.5 & 169.6 & 187.1 & 196.9 \\
Lithuania & 149.7 & 157.1 & 150.1 & 138.2 & 137.1 & 70.2 & 74.8 & 148.8 & 72.4 & 105.7 \\
Latvia & 155.0 & 157.6 & 162.9 & 164.5 & 156.1 & 89.5 & 115.8 & 119.3 & 81.3 & 114.7 \\
Estonia & 96.8 & 98.2 & 94.5 & 92.4 & 78.6 & 63.5 & 66.8 & 66.1 & 70.8 & 72.4 \\
Finland & 128.2 & 119.4 & 125.3 & 127.2 & 124.8 & 138.1 & 144.3 & 153.5 & 153.4 & 162.6 \\
Sweden & 236.1 & 229.7 & 201.8 & 210.7 & 179.8 & 150.1 & 176.8 & 171.9 & 202.9 & 198.0 \\
Norway & 2337.4 & 2366.5 & 2479.6 & 2562 & 2178.1 & 2046.9 & 1943.9 & 2135 & 2146.1 & 1872.6 \\
\hline
\end{tabular}

Source: as for Figure 2.

In the food industry, aquatic organisms are among the most important groups of products being a subject of international trade. As pointed out by Hryszko et al. (2014), the prices of raw materials and the extending chain of creating value added of products are mainly responsible for the significant trade growth rate. This process consists in catching aquatic organisms in one country, processing them in another country, and then selling the same organisms in a highly processed form to final recipients (in another country again).

In the majority of the Baltic Rim countries, over the analysed years, we can observe the increase in the value of both import and export (Table 2). The only countries recording the decrease in trade are Estonia (import by nearly 5\%) and Finland (export by more than 15\%). An interesting phenomenon was the decrease in both export and import in all Baltic Rim countries in 2015 (in export by 12.2\% against 2014 and in import by 11.6\%). A similar situation occurred in 2009, although the reasons for this trend are different. While in 2009 the main reason was the financial crisis, in 2015 the decrease in the volumes resulted from, e.g. the introduction of restrictions with regard to sale of fish from board. The largest increase in the analysed values was recorded by Sweden (increase in export by $168.8 \%$ and in import by $108.1 \%$ against 2007) and Poland (increase in export by $99.8 \%$ and in import by $111.2 \%$ against 2007). 
Table 2

Export and import of fisheries products in 2007-2016 in the Baltic Rim countries

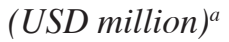

\begin{tabular}{|c|c|c|c|c|c|c|c|c|c|c|}
\hline \multicolumn{11}{|c|}{ Export } \\
\hline & 2007 & 2008 & 2009 & 2010 & 2011 & 2012 & 2013 & 2014 & 2015 & 2016 \\
\hline Denmark & 3414.8 & 3685.9 & 3100.1 & 3218.2 & 3639.3 & 3409.2 & 3836.2 & 3920.6 & 3575.9 & 3867.6 \\
\hline Germany & 2127.4 & 2315.1 & 2256.1 & 2353.6 & 2826.3 & 2749.6 & 2968.8 & 3171.2 & 2719.9 & 2858.5 \\
\hline Poland & 946.6 & 1167.7 & 1094.0 & 1329.7 & 1493.3 & 1447.2 & 1828.2 & 1905.4 & 1695.3 & 1891.6 \\
\hline Lithuania & 255.4 & 287.0 & 330.5 & 376.4 & 418.5 & 390.7 & 463.1 & 555.8 & 531.8 & 582.0 \\
\hline Latvia & 160.5 & 214.7 & 170.9 & 174.0 & 208.2 & 244.8 & 283.8 & 239.3 & 188.1 & 202.2 \\
\hline Estonia & 144.8 & 153.6 & 144.6 & 196.8 & 227.5 & 252.0 & 265.6 & 248.9 & 199.7 & 152.8 \\
\hline Finland & 48.5 & 49.6 & 50.3 & 46.6 & 52.0 & 58.6 & 60.2 & 54.9 & 40.6 & nd \\
\hline Sweden & 1650.9 & 1902.0 & 2042.0 & 2660.1 & 2865.0 & 2875.1 & 3594.8 & 3888.2 & 3677.0 & 4437.6 \\
\hline Norway & 6303.8 & 6953.2 & 7089.8 & 8873.4 & 9477.4 & 8925.8 & 10383.2 & 10823.5 & 9206.6 & 10808.6 \\
\hline \multicolumn{11}{|c|}{ Import } \\
\hline & 2007 & 2008 & 2009 & 2010 & 2011 & 2012 & 2013 & 2014 & 2015 & 2016 \\
\hline Denmark & 2346.0 & 2423.9 & 1987.7 & 2224.5 & 2539.5 & 2495.6 & 2734.9 & 2926.4 & 2627.4 & 2898.9 \\
\hline Germany & 4322.0 & 4512.3 & 4618.6 & 4753.0 & 5618.7 & 5404.1 & 5800.4 & 6265.5 & 5379.7 & 5714.3 \\
\hline Poland & 1010.4 & 1275.7 & 1207.5 & 1503.4 & 1601.9 & 1536.0 & 1993.9 & 2082.5 & 1820.8 & 2133.9 \\
\hline Lithuania & 238.6 & 289.0 & 298.1 & 349.6 & 357.8 & 365.8 & 441.4 & 507.6 & 448.5 & 537.7 \\
\hline Latvia & 109.8 & 144.2 & 118.5 & 134.7 & 168.5 & 191.0 & 228.1 & 191.4 & 153.0 & 176.4 \\
\hline Estonia & 128.7 & 143.3 & 99.5 & 119.2 & 153.7 & 172.0 & 216.9 & 202.9 & 165.5 & 122.4 \\
\hline Finland & 321.0 & 341.9 & 342.6 & 392.7 & 459.6 & 443.0 & 527.5 & 515.9 & 407.7 & nd \\
\hline Sweden & 2493.3 & 2743.9 & 2616.1 & 3273.2 & 3630.9 & 3608.8 & 4479.8 & 4771.2 & 4407.0 & 5188.7 \\
\hline Norway & 1110.8 & 1228.6 & 1192.3 & 1124.2 & 1363.9 & 1384.0 & 1303.0 & 1385.1 & 1259.7 & 1269.4 \\
\hline
\end{tabular}

${ }^{a}$ Commercial classification of fisheries products consistent with CN: codes 0301-0307.

Source: own study based on the OECD database.

Along with the increase in international trade in marine organisms, the consumption of fish is growing. As indicated by the report of the United Nations Food and Agriculture Organisation FAO (FAO, 2016), the consumption of fish over the last decades has gradually grown from a level of less than $10 \mathrm{~kg}$ per capita a year in the 1960s to the level of more than $20 \mathrm{~kg}$ in 2016. 

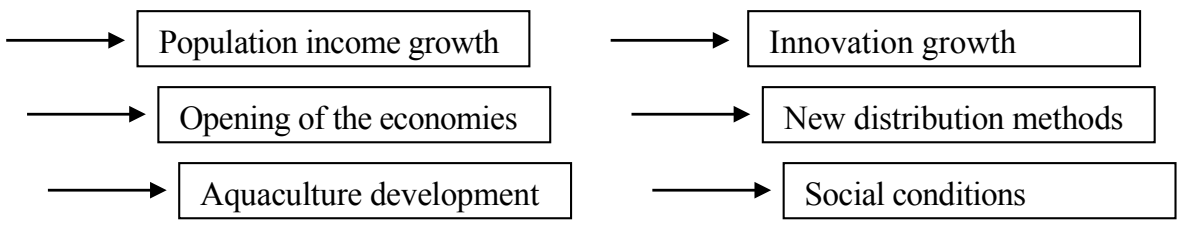

Fig. 3. Major factors determining the increased consumption of fish.

Source: own study.

Portugal and Norway are the leaders among the European countries (respectively, about $60 \mathrm{~kg}$ and $50 \mathrm{~kg}$ per capita a year). What is evident are the consumers' preferences which moved from the consumption of cheap low-quality fish, to the consumption of higher quality fish considered to be intended for more wealthy consumers. The main determinant of the development in the consumption of fish can be found in many areas presented in Figure 3.

\section{Results of the studies}

During the studies, the following groups of indices were used:

- Index of the volume of fish catches (tonnes of live weight)/fleet size (total tonnage of the fishing fleet in gross tonnes). This indicator illustrates the fishing capacity level of each country (the higher it is, the higher is the level of competitiveness achieved by the given state). When analysing the index (Fig. 4), it must be concluded that the greatest capacity in this area belongs to Denmark (index value equal to 10.4), followed by the Scandinavian countries (values from 6.0 for Norway to 8.5 for Finland). The lowest used gross tonnage is in Lithuania and Germany (indices at the level of 2.8 and 3.4, respectively).

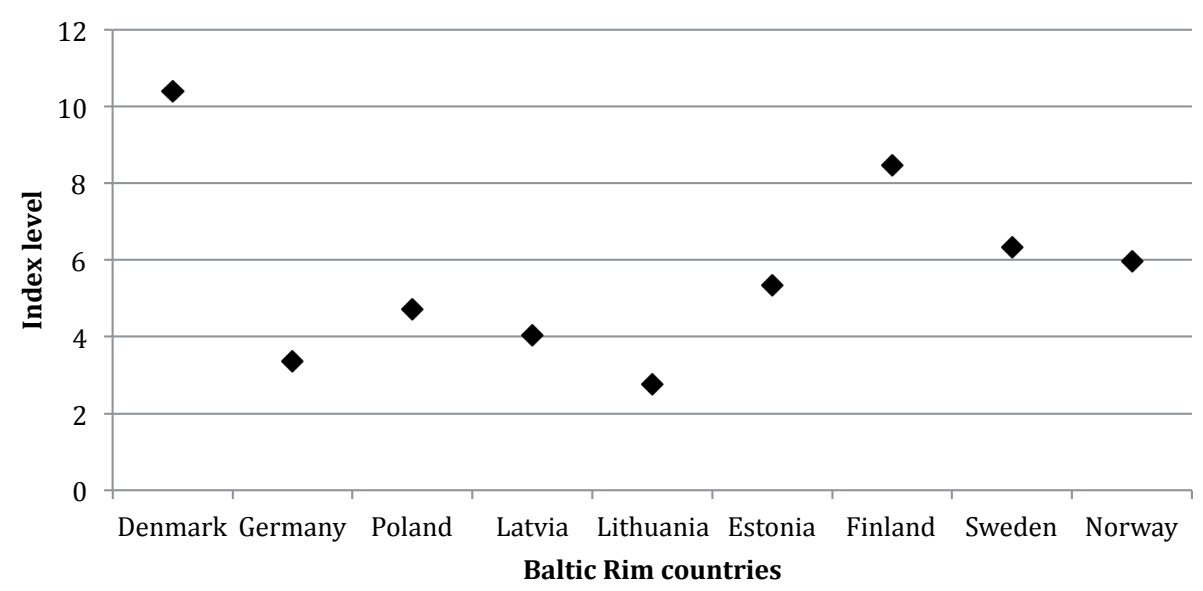

Fig. 4. Average value of index being a ratio of the volume of fish catches (tonnes of live weight) to the fleet size (total tonnage of the fishing fleet in gross tonnes) in the Baltic Rim countries for 2007-2016.

Source: as for Figure 2. 
- Index of the volume of fish catches (tonnes of live weight)/population (number of people). The index illustrates the volume of catches per capita in the given country. The higher it is, the higher is the extent to which the country is able to meet the demand of the society for fish products (the more competitive it is in relation other countries). As can be deduced from the study of this index (Fig. 5), the largest percentage of catches per capita is that of Norway (44.7 tonnes of live weight per capita), followed by Denmark (12.8 tonnes of live weight per capita). Other countries show a much lower level of this index (almost twice lower values in relation to Denmark occupying the second place). The lowest percentages are those of Germany and Poland (respectively, 0.3 and 0.4 tonnes of live weight per capita).

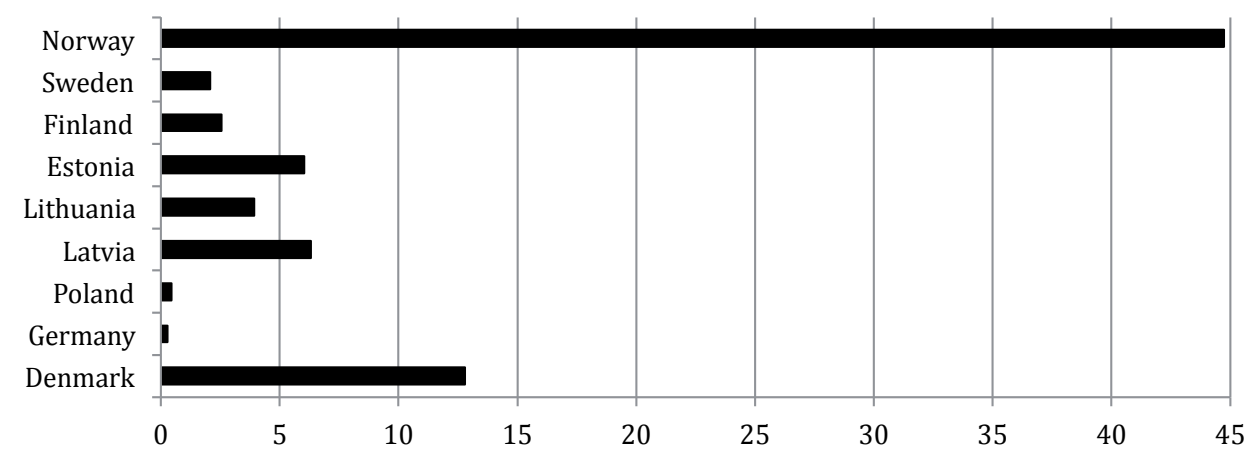

Fig. 5. Average value of index being a ratio of the volume of fish catches (tonnes of live weight) to the population number of people) in the Baltic Rim countries for 2007-2016.

Source: as for Figure 2.

- Index of the aquaculture production rate (tonnes of live weight)/volume of catches (tonnes of live weight). This index shows the level of the development of aquaculture as the major determinant influencing the future development of the fish market (Fig. 6). The highest level of the development of aquaculture in relation to catches is in Norway (50.9\% of the share), which is the only Baltic country where more raw materials are provided by own farming and rearing than sea catches. The high level of the index is also held by Poland and Germany ( $22.4 \%$ and $15.2 \%$, respectively). The region with the lowest level of competitiveness, focused on the traditional way of acquiring raw material, is the region of the post-Soviet states (the share of which is between $0.6 \%$ and $2.7 \%$ ). 


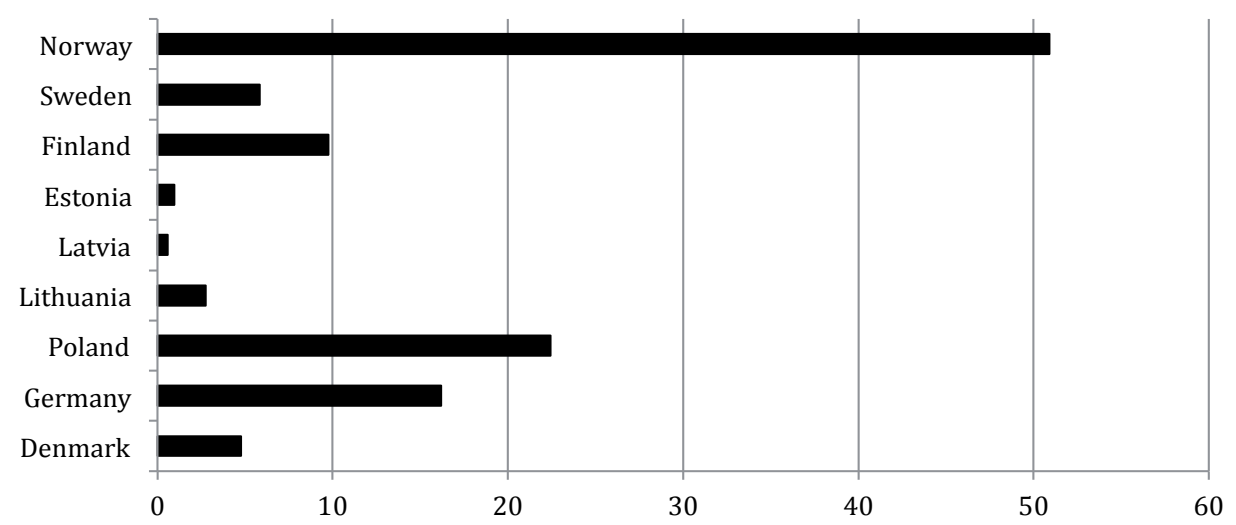

Fig. 6. Average value of index being a ratio of the aquaculture production rate (tonnes of live weight) to the volume of catches (tonnes of live weight) in the Baltic Rim countries for 2007-2016. Source: as for Figure 2.

- Efficiency indicator, measured by the Data Envelopment Analysis (DEA), focused on maximising outputs. This method adopts one output $(\mathrm{y})$ - the total production including the volume of catches and aquaculture production (tonnes of live weight) and one input (x) - the number of people engaged in catches, aquaculture production and processing (in persons). The relative efficiency was determined based on comparing the individual Baltic Rim countries with the unit that most efficiently turns inputs into outputs. The highest efficiency in the analysed years is characteristic of Norway (Table 3). It shall determine the limits of a set defining the production capacity of the analysed states. Denmark is the closest to this set (difference by $5.45 \%$ against Norway), so is Latvia (difference by $19.59 \%$ against Norway). Other Baltic Rim countries have a relative efficiency level of less than $50 \%$.

Table 3

Relative efficiency determined based on the basic DEA model focused on maximising outputs in 2007-2016

\begin{tabular}{lcc}
\hline & Efficiency & Relative efficiency index \\
\hline Denmark & 108.97 & 94.55 \\
Germany & 25.83 & 22.42 \\
Poland & 8.43 & 7.32 \\
Lithuania & 37.17 & 32.25 \\
Latvia & 92.67 & 80.41 \\
Estonia & 15.93 & 13.82 \\
Finland & 33.37 & 28.95 \\
Sweden & 57.26 & 49.68 \\
Norway & 115.25 & 100.00 \\
\hline
\end{tabular}

Source: own study based on the Eurostat database and OECD. 
- Trade coverage index (TC), which represents the extent of coverage of the import by the export (Table 4). The main objective of calculating this index is to determine the export specialisation of the analysed state on the analysed market. The desired level of the index is more than 1, which will prove the strong competitive position in the analysed area. The balance over 1 in 2007-2016 is found in five Baltic Rim countries (Table 4). The highest relative surplus occurs in Norway, where the export value, on average, exceeds the import value by more than 7 times. Other countries are Denmark, Latvia and Estonia (the average level from 1.3072 to 1.4219). The smallest share was recorded in Finland (only 0.1252).

Table 4

TC index in 2007-2016 in the Baltic Rim countries

\begin{tabular}{lccccccccccc}
\hline Country & 2007 & 2008 & 2009 & 2010 & 2011 & 2012 & 2013 & 2014 & 2015 & 2016 & średnia \\
\hline Denmark & 1.46 & 1.52 & 1.56 & 1.45 & 1.43 & 1.37 & 1.40 & 1.34 & 1.36 & 1.33 & 1.42 \\
Germany & 0.49 & 0.51 & 0.49 & 0.50 & 0.50 & 0.51 & 0.51 & 0.51 & 0.51 & 0.50 & 0.50 \\
Poland & 0.94 & 0.92 & 0.91 & 0.88 & 0.93 & 0.94 & 0.92 & 0.92 & 0.93 & 0.89 & 0.92 \\
Lithuania & 1.07 & 0.99 & 1.11 & 1.08 & 1.17 & 1.07 & 1.05 & 1.10 & 1.19 & 1.08 & 1.09 \\
Latvia & 1.46 & 1.49 & 1.44 & 1.29 & 1.24 & 1.28 & 1.24 & 1.25 & 1.23 & 1.15 & 1.31 \\
Estonia & 1.13 & 1.07 & 1.45 & 1.65 & 1.48 & 1.47 & 1.22 & 1.23 & 1.21 & 1.25 & 1.32 \\
Finland & 0.15 & 0.15 & 0.15 & 0.12 & 0.11 & 0.13 & 0.11 & 0.11 & 0.10 & bd & 0.13 \\
Sweden & 0.66 & 0.69 & 0.78 & 0.81 & 0.79 & 0.80 & 0.80 & 0.81 & 0.83 & 0.86 & 0.78 \\
Norway & 5.68 & 5.66 & 5.95 & 7.89 & 6.95 & 6.45 & 7.97 & 7.81 & 7.31 & 8.51 & 7.02 \\
\hline
\end{tabular}

Source: as for Figure 2.

Table 5 presents the final results of the study on the competitiveness of the fish industry in the Baltic Rim countries. The level of competitiveness of the fish industry in the region is characterised by considerable diversity. The dominant state in each analysed aspect is Norway, but it has a lower level of use of the fishing fleet tonnage against the countries such as Denmark, Finland and Sweden. The country with a significant degree of development of the fish industry is also Denmark. Although its overall contribution to the fisheries sector in the Danish economy is small, it is increasingly important in specific regions. At the same time, Denmark is one of pioneers in implementing modern production systems, especially in the use of by-products during fish processing (Thrane, Nielsen and Christensen, 2009).

DEA analysis showed that the state which is the least efficient in turning inputs into outputs is Poland, and thus the country with one of the largest shares in fish catches and aquaculture production. This is due to the unprofitability of human resources used. A negative phenomenon in the Baltic Rim countries is still the low share in the total production and aquaculture production (with the exception of Norway), although between 2015 and 2007 there was an average increase in the Baltic Rim countries by $56.54 \%$. 
Table 5

Compensated results of the study of the competitiveness of the fish industry in the Baltic Rim countries

\begin{tabular}{lcccccc}
\hline \multirow{2}{*}{ Country } & W1 & W2 & W3 & W4 & W5 & \multirow{2}{*}{ Sum } \\
\cline { 2 - 5 } & & & Weight & & \\
\cline { 2 - 5 } Denmark & 0.3 & 0.1 & 0.2 & 0.1 & 0.3 & \\
Germany & 5 & 4.5 & 2.5 & 4.5 & 4.5 & 4.25 \\
Poland & 1,5 & 1 & 4 & 2 & 1.5 & 2 \\
Lithuania & 2,5 & 1.5 & 4.5 & 1 & 2.5 & 2.65 \\
Latvia & 2 & 3 & 2 & 3 & 3 & 2.5 \\
Estonia & 1 & 4 & 1 & 4 & 3.5 & 2.35 \\
Finland & 4,5 & 3.5 & 1.5 & 1.5 & 4 & 2.9 \\
Sweden & 4 & 2.5 & 3.5 & 2.5 & 1 & 2.85 \\
Norway & 3,5 & 2 & 3 & 3.5 & 2 & 2.95 \\
\hline Sounce: & & 5 & 5 & 5 & 5 & 4.55 \\
\hline
\end{tabular}

Source: own study.

The TC index shows that Norway is the leader focused on export (Table 5). Opposite extreme values are adopted by Finland, which is the main importer. The remaining countries can be classified into three groups: countries more focused on export, but where import also plays a great role (Denmark, Estonia, Latvia), countries that are on the verge of the importance of export and import (Lithuania, Poland, Sweden) and countries more focused on import, but where export also plays a great role (Germany).

\section{Conclusions}

The level of evolution of the individual indices showed that there is a considerable diversity in terms of the level of competitiveness of the fish industry in the Baltic Rim countries, with the diversification as regards the development of aquaculture, importance of foreign trade in fish products and importance of the entire fish market. The results of the studies carried out allowed to make the following conclusions:

1 The fish industry in the Baltic Rim countries is one of the most important sections of the food market, the operation of which has a significant impact on the total economy and should therefore be treated as an important part of the economic space of those countries.

2. The largest level of fish catches was recorded in Denmark, then in the Scandinavian countries, and the gross tonnage is least used in Lithuania and Germany.

3. The highest percentage of catches per capita is in Norway, then in Denmark, and the remaining countries show the much lower level of this index. The lowest percentages are those of Germany and Poland. 
4. The level of the development of aquaculture can still be considered as the major determinant affecting the future development of the fish market. The highest level of the development of aquaculture in relation to catches occurs in Norway, the high level of the index is also noted by Poland and Germany. The region with the lowest level of competitiveness, which focused on the traditional way of acquiring raw material, is the region of the post-Soviet states.

5. The highest efficiency in the analysed years is characteristic of Norway, followed by Denmark and Latvia, and the remaining Baltic Rim countries are characterised by the low level of efficiency.

6. The highest export value, on average, exceeding the import value by more than 7 times is in Norway, then in Denmark, Latvia and Estonia. The lowest share is in Finland.

7. Poland is the least efficient state as regards turning inputs into outputs, despite the fact that it has one of the highest shares in fish catches and aquaculture production, which is due to the unprofitability of the use of human resources.

Based on the studies, the states can also be divided into four zones:

1. Countries with the highest level of competitiveness for which the fish industry is an important activity, with the significant efficiency of resources used (Norway and Denmark);

2. Countries with the high degree of competitiveness and high importance of the fish industry, however, which are largely based on traditional catches but are shifting slowly to the aquaculture production (Sweden, Estonia, Finland);

3. Countries with the significant level of competitiveness, yet having the low level of use of human resources in the industry and the low degree of possibilities to meet the country's fish needs (Poland, Lithuania);

4. Countries with the lowest level of competitiveness for which the fish industry is the least important activity, significantly differing from other Baltic Rim countries in many areas considered (Latvia, Germany).

The model used in the study allowed to compare the fish industry among the individual countries and to outline what makes the given country more competitive in this particular field against other countries. It also made it possible to identify the weaknesses and strengths of each country in the analysed industry. Some limitations of the adopted model may be involved with the use of the DEA index, which makes it necessary to refer cautiously to the results obtained with this model. It should also be remembered that the weight of the individual indices will undergo changes in the case of further development of aquaculture.

It is reasonable to continue to observe changes in the given determinants affecting the level of competitiveness, due to the fact that they are a basis for taking action in both short and long term. It is also recommended to check the other indices that can replace the DEA index, which will allow to increase the credibility of the fish industry's efficiency level. 


\section{References}

Batzios, C., Kaimakoudi, E., Polymeros, K. (2014). Investigating Export Performance and Competitiveness of Balkan and Eastern European Fisheries Sector. Procedia Economics and Finance, no. 9, pp. 219-230.

Bergheim, A. (2012). Recent growth trends and challenges in the Norwegian aquaculture industry. Latin American Journal of Aquatic Research, no. 40(3), pp. 800-807.

Eesti Statistika (2017). Eesti Statistika Kvartalikiri - Ülevaade Eesti sotsiaalja majanduselus toimunust, no. 2.

European Maritimie and Fisheries Fund Lithuania (2014). European Comission Report.

FAO (2016). The State of World Fisheries and Aquaculture 2016. Contributing to food security and nutrition for all.

Filip, P., Sowa, B. (2008). Konkurencja podatkowa jako efekt globalizacji gospodarki światowej. In: Najnowsze zmiany polskiego prawa prywatnego i publicznego a funkcjonowanie rynków finansowych (pp. 323-340). Rzeszów: TNOiK O/Rzeszów.

Firlej, K., Kubala, S. (2017). Factors of Functioning and Chances of Development of Fish Industry in Poland. Acta Scientiarum Polonorum, Oeconomia, no. 16(2), pp. 33-43.

Gorynia, M. (2000). Luka konkurencyjna w przedsiębiorstwach a przystąpienie Polski do UE. Gospodarka Narodowa, no. 10, pp. 48-67.

Grzebyk, M., Kryński, Z. (2011). Konkurencja i konkurencyjność przedsiębiorstw. Nierówności Społeczne a Wzrost Gospodarczy, no. 20, pp. 107-117.

Hameri, A., Palsson, J. (2003). Supply chain management in the fishing industry: the case of Iceland. International Journal of Logistics, no. 6(3), pp. 137-149.

Hryszko, K., Kuzebski, E., Lirski, A. (2014). Sytuacja na światowym rynku ryb i jej wpływ na rozwój sektora rybnego $w$ Polsce. Program Wieloletni 2011-2014, no. 106. Warszawa: IERiGŻ-BIP.

Kukuła, K., Strojny, J. (2010). Ocena konkurencyjności międzynarodowej polskiej branży mięsnej w oparciu o koncepcję atrakcyjności i pozycji rynkowej. Metody Ilościowe w Badaniach Ekonomicznych, t. XI/2, pp. 171-180.

Latrufee, L. (2010). Competitiveness, Productivity and Efficiency in the Agricultural and AgriFood Sectors. OECD Food, Agriculture and Fisheries Papers, 30, OECD Publishing.

Ludwiczak, B. (2014). Wykorzystanie metody DEA w przestrzenno-czasowej analizie efektywności inwestycji. Nierówności Społeczne a Wzrost Gospodarczy, no. 39, pp. 419-431.

Pierścionek, Z. (2003). Strategie konkurencji i rozwoju przedsiębiorstwa. Warszawa: PWN.

Rucinski, P., (2017). Fish and Seafood Market in Latvia. GAIN Report. Retrieved from: https://gain.fas.usda.gov/Recent\%20GAIN\%20Publications/Fish\%20and\%20Seafood\%20 Market\%20in\%20Latvia.\%20_Warsaw_Latvia_1-11-2017.pdf.

Thrane, M., Nielsen, E.H., Christensen, P. (2009). Cleaner production in Danish fish processing - experiences, status and possible future strategies. Journal of Cleaner Production, no. 17 , pp. $380-390$.

Urbaniak, W. (2007). Konkurencyjność - próba zdefiniowania zjawiska. Acta Universitatis Lodziensis, Folia Oeconomica, no. 204, pp. 243-252. 


\title{
BADANIE POZYCJI KONKURENCYJNEJ BRANŻY RYBNEJ W REGIONIE KRAJÓW NADBAŁTYCKICH
}

\begin{abstract}
Abstrakt
Głównym celem artykułu była próba określenia pozycji konkurencyjnej branży rybnej w krajach regionu nadbałtyckiego. W wyniku obecnych uwarunkowań społeczno-gospodarczych w poszczególnych państwach nadbałtyckich wystepuje zróżnicowany poziom zapotrzebowania na produkty rybne, rozwoju handlu zagranicznego, czy też odmienne możliwości uzyskiwania organizmów rybnych przez rozwój akwakultury. W wyliczeniach zastosowano metody takie jak indeks DEA i wskaźnik TC. Wyniki obrazujące poziom kształtowania się wskaźników wykazały znaczny stopień zróżnicowania efektywności branży rybnej w państwach nadbałtyckich, przy jednoczesnym zróżnicowaniu pod względem rozwoju akwakultury, znaczenia handlu zagranicznego produktami rybnymi, jak $i$ znaczenia całego rynku ryb. W artykule wykorzystano wskaźniki określajace poziom funkcjonowania branży w badanych państwach, a na ich podstawie dokonano jej oceny punktowej.
\end{abstract}

Słowa kluczowe: branża rybna, akwakultura, połowy ryb, flota rybacka.

Accepted for print: 15.06.2018.

Unless stated otherwise all the materials on the website are available under 